$$
\begin{aligned}
& S K 357 \\
& .46
\end{aligned}
$$





\section{COMMITTEE ON THE PUBLIC LANDS HOUSE OF REPRESENTATIVES}

\section{LOCH-KATRINE BIRD RESERVATION}

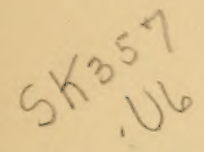

CORRESPONDENCE BETWEEN

HON. F. W. MONDELL

CHAIRMAN OF THE COMMITTEE ON THE PUBLIC LANDS

OF THE HOUSE OF REPRESENTATIVES

AND

DR. T. S. PALMER

IN CHARGE OF GAME PRESERVATION, BIOLOGICAL SURVEY, DEPARTMENT OF AGRICULTURE

RELATIVE TO EXECUTIVE AUTHORITY

FOR THE RESERVATION OF LANDS

AS BIRD PRESERVES 


$$
5 K^{351} .06
$$

FEB 11909

$\therefore \vdots$ 


\title{
LOCH-KATRINE BIRD RESERVATION.
}

\author{
[No. 961.] \\ EXECUTIVE ORDER.
}

It is hereby ordered that all of the lands embraced within the meander survey of a reservoir site located in what is commonly known as the Oregon Basin, embracing five thousand five hundred acres, more or less, in section five, township fifty-one north, range one hundred west, and sections nineteen, twenty, twenty-one, twenty-two, twenty-seven, twenty-eight, twenty-nine, thirty, thirtyone, thirty-two, thirty-three, and thirty-four, township fifty-two north, range one hundred west of the sixth principal meridian, Wyoming, together with a strip of land fifty feet wide adjoining said meander survey on the outside and surrounding said reservoir site, as the said reservoir site appears upon the map of the Shoshone River canal, on file in the General Land Office, approved March 13,1903 , and as the same is shown by the broken line upon the diagram hereto attached and made a part of this order, are hereby reserved, subject to valid existing rights, and set aside for the use of the Department of Agriculture as a preserve and breeding ground for native birds. The taking or destruction of birds' eggs and nests, and the taking or killing of any species of native birds for any purpose whatever, except under such rules and regulations as may be prescribed by the Department of Agriculture, is prohibited, and warning is expressly given to all persons not to commit any of the acts hereby enjoined. This reserve to be known as the Loch-Katrine Reservation.

The White House, October 26, 1908.

Theodore Roosevelt.

United States Department of Agriculture, Bureau of Biological Survey, Washington, D. C., January 5, 1909.

Hon. F. W. Mondell,

Chairman Committee on the Public Lands, House of Representatives.

DeAR SIR: In compliance with the request contained in your letter of January 2, I inclose herewith another copy of Executive Order No. 961, establishing the Loch-Katrine Reservation in Wyoming.

In reply to your inquiry concerning the authority for the establishment of the reservation, I beg to say that these bird refuges, like 
other federal reserves established by executive order, are simply reservations of public land for public use. They differ in purpose, though not in principle, from reservations established for military purposes, naval stations, light-house sites, sea otter reserves, reindeer stations, and other public uses. So far as I am aware, no specific act exists providing for the establishment of such reservations. They have been created by authority of the President in accordance with a practice which dates back to the earliest history of the Government and which has been repeatedly approved by Congress and sustained by decisions of the Supreme Court. Among the decisions bearing on this point may be cited: Wolcott $v$. Des Moines Co. (5 Wall., 688), Grisar v. McDowell (6 Wall., 363), and Wolsey v. Chapman (101 U. S., 755).

In Grisar $v$. McDowell, involving the reservation of a tract of land in the city of San Francisco for military purposes, the Supreme Court declared:

From an eariy period in the history of the Government it has been the practice of the President to order, from time to time, as the exigencies of the public service required, parcels of land belonging to the United States to be reserved from sale and set apart for public uses.

The authority of the President in this respect is recognized in numerous acts of Congress. Thus in the preemption act of May 29, 1830, *** in the preemption act of September 4, 1841, *** the act of March 3,1853, providing for the survey of the public lands in California. * * *

The action of the President in making the reservations in question was indirectly approved by the legislation of Congress in appropriating moneys for the construction of fortifications and other public works upon them (p. 381).

This question is fully discussed in an opinion of the AttorneyGeneral submitted to the Secretary of the Interior regarding the Southern Pacific Railroad grant (16 Op. Atty. Gen., 87), and more recently in an opinion submitted by the Assistant Attorney-General to the Secretary of the Interior on June 17, 1890, regarding reservations in Alaska.

I may add that Congress has indirectly approved the establishment of these bird reservations in the act of June 28, 1906, "To protect birds and their eggs in game and bird preserves," by prohibiting the capture of birds or the taking of eggs "on any lands of the United States which have been set apart or reserved as breeding grounds for birds by any law, proclamation, or executive order." (34 Stat., 536.)

Respectfully,

T. S. PALMer, In Charge of Game Preservation.

Mr. T. S. Palmer,

In Charge of Game Preservation, Bureau of Biological Survey, Washington, D. C..

SIR: I have the honor to acknowledge receipt of your letter of January 5 , in reply to a request contained in my letter of January 2, in which I made inquiry concerning the authority for the establishment of the Loch-Katrine Reservation, and I note that you say that "these bird refuges, like other federal reserves established by executive order, are simply reservations of public land for public use." You state further that " they differ in purpose, though not in principle, 
from reservations established for military purposes, naval stations, light-house sites, sea-otter reserves, reindeer stations, and other public uses." You also state that so far as you are aware "no specific act exists providing for the establishment of such reservations," but that "they have been created by authority of the President in accordance with a practice which dates back to the earliest history of the Government and which has been repeatedly approved by Congress and sustained by decisions of the Supreme Court."

I note that in the closing paragraph of your letter you say:

I may add that Congress has indirectly approved the establishment of these bird reservations in the act of June 28, 1906, "To protect birds and their eggs in game and bird preserves."

I have very carefully considered the statements contained in your letter, have read the decisions to which you refer, as well as the act of Congress title of which you quote, and I must say that I am utterly unable to agree with your conclusions as to executive authority touching the matters referred to, nor do I find support for the views you express in any of the authorities to which you refer.

Before entering on a discussion of the question as to the limitations of executive authority so far as it pertains to public lands, I desire to call your attention to the fact that the lands described in Executive Order No. 961, known as the Loch-Katrine Reservation, are not public lands, and therefore could not be lawfully reserved by the President for any purpose whatever, even though the President had authority to create such reservations on public lands.

The lands described in the above-mentioned order are, as stated in the order, a part of the right of way of the Shoshone River Canal, approved March 13, 1903. This right of way is a congressional grant, and the lands embraced within it have been definitely determined by the approval of a map of the same, and the title is vested in the owners of the Shoshone River Canal and subject to taxation and control as any other land in private ownership in the State of Wyoming.

Assuming for the sake of argument that the Executive has authority to establish reservations of this kind on public lands, surely no one will contend that any authority is vested in the Executive to create a public reservation on private land. If such an act as this were valid, then all the rights of way of all of the railroads in all of the public-land States could be made bird refuges or game preserves, for those rights of way were granted under statutes similar in all essential particulars to that under which the right of way in question was granted.

I desire, however, to emphatically protest against the theory that the President or anyone else has authority to reserve public lands as bird or game refuges or as bird or game preserves, or for any such like purpose, and the decisions cited certainly do not warrant the view that the President has such authority.

The case of Wolcott $v$. Des Moines Co. (5 Wall., 688) relates to reservations made by executive authority in accordance with the provisions of an act of Congress. The Congress had in 1846 granted to the Territory of Iowa, for the purpose of aid in the improvement of navigation on the Des Moines River, alternate sections of the public lands in a strip of 5 miles in width on each side of the Des Moines River. The only question at issue was whether a certain tract of land, designated by executive authority in pursuance of law, was a 
portion of the land granted by the act of Congress for the purpose of enabling the Territory to aid in the improvement of the Des Moines River.

To hold that this decision offers the slightest excuse for the executive act now under discussion is, it occurs to me, a most extraordinary torturing of the plain intent and effect of the decision.

The extract from the decision in Grisar v. McDowell (6 Wall., 363), quoted by you in your letter, has, I realize, been repeatedly used as an excuse for the claim of executive authority to withdraw lands, but will certainly bear no such construction as that now placed upon it, for unquestionably in using the term "for public uses" the court had in mind public uses of the character of that for which the tract in question in the case before the court was reserved, to wit, for military purposes.

No one has ever denied the right of the Executive to reserve land required for military purposes, for light-houses, or the like. In this case the question was, Did the Executive have the authority to set aside land for the military use of the Government?

The integrity of the nation, the lives of its citizens may depend upon the reservation of land for military and light-house purposes. They are clearly public purposes, such as the court had in mind when it passed upon this case involving the title to a military reservation, but it has been held by high authority that the authority of the Executive to withdraw land even for military purposes is a limited one, as was very clearly pointed out by Secretary Lamar in the case of the Fort Boise Reservation (6 L. D., 16), in which a reservation was made by the War Department of more than the 640 acres authorized by the act of Congress of February 14, 1853.

The case of Wolsey $v$. Chapman (101 U. S., 755), to which you refer, is another case relating to the Des Moines River grant, and the reservations made under that grant were clearly made by authority of Congress. The only question at issue was as to whether the lands in controversy were a part of the grant. The most strained and extravagant interpretation of this decision can not by any possibility torture it into a justification of executive withdrawals or reservations, confessedly not based on any act of Congress.

I have examined with care the opinion of the Attorney-General submitted to the Secretary of the Interior regarding the Southern Pacific Railroad grant (16 Op. Atty. Gen., 87), to which you refer. I find that the opinion relates to a grant to the Southern Pacific Railroad made by Congress. The question in controversy was whether the Secretary of the Interior had erred in withdrawing certain lands as being part of the grant. There is nothing whatever in the case touching the right or authority of anyone to withdraw lands without definite and specific authority of law. The Attorney-General calls attention to the fact that the Secretary of the Interior may in certain cases be in doubt "whether a greater or less amount (of land) should be withdrawn in order to protect the grants or comply with other legislation of the United States." There is no claim that this reservation in question is made with a view of complying with legislation of the United States.

I can not refrain from expressing surprise at the rather extraordinary statement in the last paragraph of your letter to the effect "I may add that Congress has indirectly approved the establishment of these bird reservations in the act of June 28, 1906," by pro- 
hibiting the capture of birds or taking of eggs "on any lands of the United States which have been set apart or reserved as breeding grounds for birds by any law, proclamation, or executive order."

I happen to be well acquainted with the history of the legislation in question, and instead of being held by the executive departments as approving directly or indirectly anything that may have been done prior to the passage of the act, it should have been accepted by the executive departments as clearly indicating the determination of Congress not to authorize the creation of any such reserves.

The first section of the bill as introduced by Mr. Lacy was as follows:

Be it enacted by the Senate and Itouse of Representatives of the United States of America in Congress assembled, That it shall be unlawful for any person to hunt, trap, capture, willfully disturb, or kill any bird of any kind whatever, or take the eggs of such birds on any lands of the United States which have already been or may hereafter be set apart or reserved as game preserves or breeding grounds for birds by any law, proclamation, or executive order, except under such rules and regulations as may be prescribed from time to time by the Secretary of Agriculture.

It will be ncted that this bill, had it become a law as introduced, would have authorized the reservation of lands as bird and game preserves, but as the bill became a law, all of that portion which I have italicized and which would have authorized the reservation in question was stricken out.

As a member of the committee that reported the bill I recall very clearly the discussion in the committee on the subject, and how earnestly Mr. Lacy, chairman of the committee, plead for the passage of the bill, and how, after it was amended by striking out all that portion which would authorize the reservation of lands for the purpose contemplated, the bill was only reported on the earnest plea of Mr. Lacy that there were only six reservations, the names, location, and extent of which were given, which it would affect, all of which were small islands, the largest containing about 28 acres. As stated by Mr. Lacy in his report, "All these islands are small in size, low, swampy, or rocky, and of no value for agricultural purposes."

It was admitted that these refuges had been established without authority of law, and that therefore there was no way of protecting the birds upon them, but on the plea that they were small, rocky, and uninhabitable, and on the distant coasts of the United States, the bill was finally reported out of the committee in the belief that while it would make it possible to protect the birds on the small outlying islands referred to it would also serve as notice to the executive departments that Congress would not authorize the setting aside of further lands for these purposes, as is clearly indicated in the last paragraph of the report on the bill, in which Mr. Lacy stated that the matter of providing for other reservations was under consideration by Congress in several bills.

Had the members of the committee reporting the bill to Congress had any idea that the view expressed in your letter would be held by the executive departments, it is safe to say that the bill would never have been reported, much less passed. Clearly" the act will not bear the strained construction you now place upon it, but that construction is certainly a splendid object lesson to legislators to be careful not to seem to condone executive action, in excess of authority, lest it be warped into an excuse for further unlawful acts.

There is one feature of this matter which your department seems to have entirely overlooked in the search of authorities in the hope 
of finding decisions which would warrant the acti taken, and that is, that the Supreme Court of the United States had decided that the Federal Government has no authority over or right to regulate the taking of game within a State. This doctrine does not rest on any strained or fantastic interpretation of decisions, but has been clearly laid down in two cases by the Supreme Court.

First. In the case of Geer $v$. Connecticut (161 U. S., 519), in which the question of the control of the State over the game within its borders was elaborately discussed, the court said, referring to the power of regulating the taking of game: "For the purpose of exercising this power, the State, as held by this court in Martin $v$. Waddell (16 Pet., 410), represents its people, and the ownership is that of the people in their united sovereignty." The court then goes on to quote with approval a decision of the supreme court of California to the effect that "the wild game within a State belongs to the people in their collective sovereign capacity," and also a decision by the supreme court of Minnesota to the effect that ownership of game is in the State in its sovereign capacity as the representative of its people in common.

In the case of Ward $v$. Race Horse (163 U. S., 505), a case in which the question at issue was as to whether the United States had authority by treaty to authorize the taking of game by Indians from a region which subsequent to the ratification of the treaty was included within the boundaries of a State, in violation of the state game laws, the court held emphatically that the Federal Government had no such authority; that the State was sovereign and absolute in its control over the game within its borders. Among other things the court said: "The power of a State to regulate and control the taking of game can not be questioned."

The court rejected the argument that the treaty conferred the right to hunt "when the United States had called into being a sovereign State, a necessary incident of whose authority was the complete power to regulate the killing of game within its borders." After citing the fact that the act which admitted Wyoming into the Union expressly declared that the State was admitted into the Union on an equal footing with the original States, the court referred to the claim that the Federal Government has the right to regulate the taking of game within the State as irreconcilably in conflict with the power of the State.

I most earnestly urge your careful consideration of these decisions, which are voluminous, exhaustive, definite, and controlling, and make it clear that the executive order in question is in direct conflict with the decisions of the Supreme Court above cited, and an attempted invasion of the rights of the State, inasmuch as it expressly enjoins, warns against, and attempts to prohibit acts which are entirely legal and lawful under the state law.

In conclusion, I desire to dissent most emphatically from the views expressed in your letter and to register my protest against the order in question, or any like orders, as being without authority of law, beyond and in excess of executive authority, in violation of the rights of the States and their citizens, and in direct conflict with the decisions of the Supreme Court of the United States.

Very respectfully, yours. 
LIBRARY OF CONGRESS

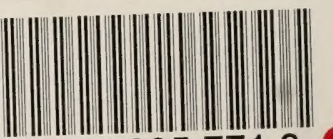
00028957713 